\title{
University Technology Incubator: Technology Transfer of Early Stage Technologies in Cross-Border Collaboration with Industry
}

\author{
Stephan Hess ${ }^{1} \&$ Roland Y. Siegwart ${ }^{2}$ \\ ${ }^{1}$ Alstom Power, Baden, Switzerland \\ ${ }^{2}$ Swiss Federal Institute of Technology, Zuerich, Switzerland
}

Correspondence: Stephan Hess, Alstom Power Switzerland. Tel: 41-44-632-2634, Fax: 41-44-6321-184. E-mail: stephan.hess@alstom.com

Received: May 7, 2013

Accepted: May 27, 2013

Online Published: May 29, 2013

doi:10.5430/bmr.v2n2p22

URL: http://dx.doi.org/10.5430/bmr.v2n2p22

\begin{abstract}
Academia has established various technology transfer channels to support the technology transformation process. However, since universities are not expected to directly approach the market, either the established industry partners have to become involved, or new enterprises have to be developed. The established industry should be prepared for an efficient, early-stage technology transfer with development alliances right across boundaries.

This paper looks at the preparation and implementation of the UTI at the Swiss Federal Institute of Technology Zürich (ETHZ) and aims to explore the specific strategic positioning and capabilities of a university technology incubator with focus on industry alliances. In a case study, the authors investigate technology screening, spin-off formation, and the alliance development phase as a collaborative innovation approach. The existing literature is reviewed and a university technology incubator method, as a "Broker of Technology", is presented.
\end{abstract}

Keywords: University technology incubator, Spin-offs, Technology transfer, Technology absorptive capacity, Technology lifecycle

JEL Classification Codes; O31, O32, O33, L2, L3, L64, L97

\section{Introduction}

Faster technology cycles, industrial globalization, scarce resources and higher energy efficiency demands are all driving industry innovation programs towards the ever earlier identification of promising new technologies. Supported by the theory of inertia, the conventional view is that established enterprises rarely introduce breakthrough technological innovation (Tornatzky and Fleischer, 1990; Tripsas, 2008); their fear of jeopardizing existing business stems from a reluctance to recognize the pace of market evolution (Gilbert, 2005). Nevertheless, in such an irregular technology lifecycle movement, established firms have to embrace innovation and must be willing to take more risks if they are to retain their market position. They need to step up their screening of early technology lifecycle phases and increase cooperation with academia (Rohrbeck et al., 2006; Burlem, 1977).

As far as an established company is concerned, innovation is usually developed by internal research and development (R\&D) to control the financial risks involved in the development phase of innovation. In addition, internal R\&D capabilities are tailored to existing products with dominant designs (Utterback and Abernathy, 1975; Gilbert, 2005; Ahuja and Lampert, 2001). Organizations which are thus optimized to internal efficiency are no longer flexible and cannot easily respond or adapt to new technologies and innovations (Christensen, 2003); their absorptive capacity (Cohen and Levinthal, 1989) for external innovation is challenged. This dilemma of successful coexistence between breakthrough and incremental innovation has been investigated and discussed in the theory of ambidexterity of firms (Tushman and O'Reilly, 1996).

Owing to substantial public funding, the pressure on research institutions and universities to innovate and efficiently transfer research results to increase socio-economic value is rising (Muscio, 2010; Mowery et al., 2010; Masterplan Cleantech Schweiz, 2010). The increasing relevance of the early technology transformation process can also be seen in the development of breakthrough technologies in academic spin-offs. Agility, speedy progress to technology demonstration and a more efficient use of resources and talents play a positive role in influencing the transformation 
process (Barringer and Bluedorn, 1999). Open innovation theory (Chesbrough, 2003) suggests "opening up" established R\&D for external breakthrough technology development (e.g., with academic spin-offs). Early industry spin-off alliances, where agile spin-offs with technology acumen and the established industry with industrialization and market know-how cooperate in developing technology, are an opportunity for an efficient early technology transfer process (Hess and Siegwart, 2012).

It is in this environment that a University Technology Incubator (UTI) can be established, supporting the transformation process and more effectively incubating academic technology ventures (Mian, 1997). The present study accompanies the preparation and implementation of the UTI at ETHZ and investigates the capabilities and set-up of a UTI aiming to improve early-stage technology transfer performance in alliance with the established industry. Becker and Gassmann (2006) state that a UTI set-up should be linked to the overall strategy of the university, although "... university incubators still have a long way to go towards clearly defined technology strategies that are similar to the ones in the corporate world" (Becker and Gassmann, 2006, p. 475). Such a situation requires new ideas and more detailed concepts in technology screening and transfer with academia, which can be complemented with the UTI "Broker of Technology" concept introduced in this study.

\section{Theories and Background}

Academic technology incubation is part of a broader relationship between universities and industry, and encompasses all features of technology transfer, from patenting, licensing, and spin-off creation, to the set-up of an industrial liaison office (Rothaermel and Thursby, 2005a). A UTI is primarily non-profit making (Wiggins and Gibson, 2003) and its main differentiation is "... the earliest point of access to technology emanating from academic research" (Etzkowitz, 2002, p. 122). It supports the incubation of technologies from research teams in various ways, including screening and identifying technology, as well as assessing and developing it. A systematic review of incubation research concludes to focus on the incubation process to explain phenomena like new venture formation, venture development, new product development and business assistance rather than on the incubator facility (Hackett and Dilts, 2004).

The basic definition of technology transfer (Pérez and Martinez, 2003, p. 824; Williams and Gibson, 1990) allows the anticipation of specific roles for a UTI in technology transfer. In the case of an academic early-stage technology, the knowledge is with the academic institute, mostly with a scientist or a team. These individuals possess specialized technical skills and primarily provide a scientific technology overview; they are well connected in the academic environment of the relevant technology (Autio, 1997). To initiate the technology transmission process, it is essential to start by identifying the potential receptors. The identification of the established industry players with the appropriate technology absorptive capacity (Cohen and Levinthal, 1989; Zahra and George, 2002; George et al., 2002), who are in a position to adopt the technology using their existing R\&D processes and know-how, allows for an early positioning of the technology and a potential direction for technology transfer.

For breakthrough technologies, where the absorptive capacity on the receptors' side is limited, and where the established industry players cannot - or do not want - to take the risk of technology diffusion, academic spin-offs may have an important role in the process of technology transfer (Hess and Siegwart, 2012; Fontes, 2005; Colombo and Delmastro, 2002). Rothaermel and Thursby (2005b) investigated the relationship of universities to incubator firm failure and found slower firm graduation, based on the early "embryonic" technology stage, and overly optimistic inventors. However, they also found that faculty involvement reduced the likelihood of failure after incubation. Spin-offs therefore need to establish a reputation and certain legitimacy; they must demonstrate that they are reliable and trustworthy business partners (Schwartz, 2009).

An important element for spin-off development is the building of partnerships or alliances. In their investigation of science parks and on- and off-park spin-off performance, Lindelöf and Löfsten (2003, p. 248) hypothesized that “... a successful (technology, authors comment) partnership constitutes an organization of the potential synergies and the dynamic complementarities between large, established firms and small, new technology-based firms." They also found that alliances offered large firms a channel with which they could tap into the innovation and entrepreneurial potential of smaller companies. With their technological expertise, internal flexibility, and agility, academic spin-offs have advantages and differentiation as technology transfer channels (Autio, 1997; Fontes, 2005; Hess and Zwicker, 2009). In this respect, Fontes (2005, p. 343) sees the spin-off in a technology and knowledge mediator role, acting as brokers or agents of knowledge and technology between academia and the established industry.

Chiesa and Piccaluga (2000), on the other hand, have found that spin-off founders perceive commercialization as "hostile for them", lacking commercial skills, they view distribution phases and channels as obstacles and are inept at estimating market demand and segmentation. On the technical side, product development and production, 
engineering and industrialization efforts are all neglected which leads to failure (Clarysse and Moray, 2004; Toole and Turvey, 2009). The problem lies with the founders, whose skills are " $R \& D$ oriented and different from those required downward to the production ..." (Chiesa and Piccaluga, 2000, p. 337). Stankiewicz (1994), describes the technology transfer role of academic spin-offs and identifies two basic modes. The first of these is the R\&D contracting mode, which exploits the competence, shortages, and bottlenecks of technology applications; the second is the technological asset-oriented mode, in which the focus is on commercialization, either directly or, for example, through licensing and joint ventures.

Pérez and Martinez (2003) have investigated the innovation activity of academic technology spin-offs during their early years and looked at the importance of the catalyzing role of innovation networks for technology transfer. Building such a network in the early phases requires significant effort and is a key element of success for future survival and development. Early networking actually strengthens mutual trust between academic spin-offs and industry partners, enabling cooperation while also providing both market information and know-how. It has been suggested to academic spin-offs that they "... actively partner with organizations with technology capabilities and financial resources they do not have themselves" (Chandy and Tellis, 2000, p. 13).

A UTI can help to identify, assess and evaluate a new technology in the academic pipeline, and may effectively "... help academics with little or no business experience to start up new firms based on technology invented in the university" (Etzkowitz, 2002, p. 124). Walter et al. (2006), found that network capability impacts spin-off performance, while entrepreneurial orientation per se has no significant direct effect on spin-off sales growth. Building absorptive capacity with building partner knowledge in a network is important to develop marketable offerings and the question "how can network capability be build up quickly after foundation" (Walter et al., 2006, p. $560)$ is central.

\section{Research Objectives}

This study blends networking in alliances perspectives for the early technology lifecycle and technology absorptive capacity perspectives. It aims to investigate the benefits of using an applied method of the UTI at ETHZ to improve early-stage technology transfer performance by promoting collaboration and alliances between academic spin-offs and the established industry. Furthermore, for practice, the research aims to explore specific strategic characteristics and the positioning of the UTI process, the alliance performance of spin-offs, and to investigate the technology screening and assessment of technology invention types and their impact on spin-off formation and on the alliance development phase. The following research question is posed:

- How does a university technology incubator support technology transfer with early stage technology spin-offs towards industrial alliances?

\section{Methods}

This research encompasses a multi-year time frame starting in 2010 to prepare the UTI at the ETHZ. ETHZ and its adjacent institutions are the largest Swiss research institutes with a strong focus on science and engineering based technology research. This study aims to view incubation starting in an early maturity stage and it prioritizes the technology perspective. In pre-evaluation interviews and informal discussions with experienced spin-off coaches and technology transfer experts, it was recommended that we exclude life- and bio-science and service spin-offs from the study, because the technology, R\&D, industrial barriers and the overall spin-off positioning and industrial settings are very different. To specify technology, we introduced the NOGA (Nomenclature Générale des Activités économiques - Swiss branch code to systematically economic enterprises analogue the EU NACE classification) classification codes for materials, mechanical devices and electrical devices.

In the time frame of 2000-2012, ETHZ launched $\sim 30$ spin-offs with the relevant characteristics. We identified 5 spin-offs from ETHZ and the adjacent institutes, who volunteered to join in a longitudinal investigation. The research participants were spin-off founders in the role of a CEO or CTO of the young firm. We baseline our understanding of the spin-offs with a structured questionnaire and subsequently met every two weeks for a two hour interview and numerous intermediate informal discussions. The interviews and meetings primarily happened in the spin-offs vicinities, often in their laboratories or production places.

Starting the UTI at ETHZ and the introduction of the supporting inventors' grant, we could investigate 5 inventors with the technology characteristics previously discussed. We participated in inventors coaching programs and alliance negotiations. We met experts from the university technology transfer and industry relation teams, as well as industry partners volunteering to be involved in the development of the UTI. The data were obtained from notes taken during these interviews and workshops and from the inventor's technology, business cases, and marketing material, as well as archival documents regarding the foundation of the spin-offs. 
The case study method was selected, as it allows for a detailed investigation and analysis of a management problem (Eisenhardt and Graebner, 2007; Yin, 2009). This paper focuses on understanding the problems and patterns of the construction of a model. The authors were part of a UTI preparation, implementation and coaching process. They were also present, often as active participants, at discussions with the inventors, spin-offs, industry alliance partners and were granted access to all the relevant inventors and managerial positions. This kind of active field research obviously develops researchers role towards a more active participation (Greenwood and Levin, 2007; Denzin and Lincoln, 2005), but the authors focus were on observation and understanding of the environment and on carrying out their research, focusing especially on the players involved. Emphasis was also placed on the phrasing of propositions for implementation, which were finally discussed with the participants in the study. Names of spin-offs and inventors have been changed to protect the companies' identities.

\section{Strategic Positioning of a University Technology Incubator as a "Broker for Technology"}

The strategic role of the ETHZ and its research institutes is defined by the Swiss Federal Assembly. The role of the ETHZ ranges from the training of students and scientific personnel, ensuring a scientific dialogue with the public, providing scientific services, and expanding scientific knowledge through research and by "exploiting their research findings" (Swiss Federal Council, 1991). Figure 1 illustrates a basic scheme at the ETHZ for technology transfer vehicles between academia and the established industry. The technology absorptive capacity of the receiving established industry defines the technology transfer measures which can apply.

Most applied research between academia and the established industry is conducted with strong R\&D cooperation. It is defined by industrial purchase orders where academic institutes cooperate with industry partners in research programs which are often externally funded. In this case, the industry partner identifies a technological need after screening, and possesses the R\&D resources necessary for the direct interaction with academia. An industry partner with a high absorptive capacity for a certain technology can license technologies of interest directly from academia. According to the license agreement, academia then transfers the technology, and the industry partner can absorb all the basic technology know-how without major R\&D efforts, and independently prepare product diffusion.

For technologies in academia where the established industry cannot assume technology knowledge and absorptive capacity is limited, the technology transfer situation remains complex. This is obviously the case for breakthrough early-stage technological innovations. Unless the industry partner declines to accept the risk of building the required technology absorptive capacity himself, and to cooperate based on R\&D purchase order agreements, he will need to instead seek a partner who takes over and develops the technology. Academic spin-offs can be positioned to be suitable partners for such joint technology development programs. When the established industry is not prepared or not interested in being a partner in a technology transfer, academia can support the building of an academic standalone technology spin-off which then bears on its own the risk of incubating the technology, building technology capability, and taking it to market.

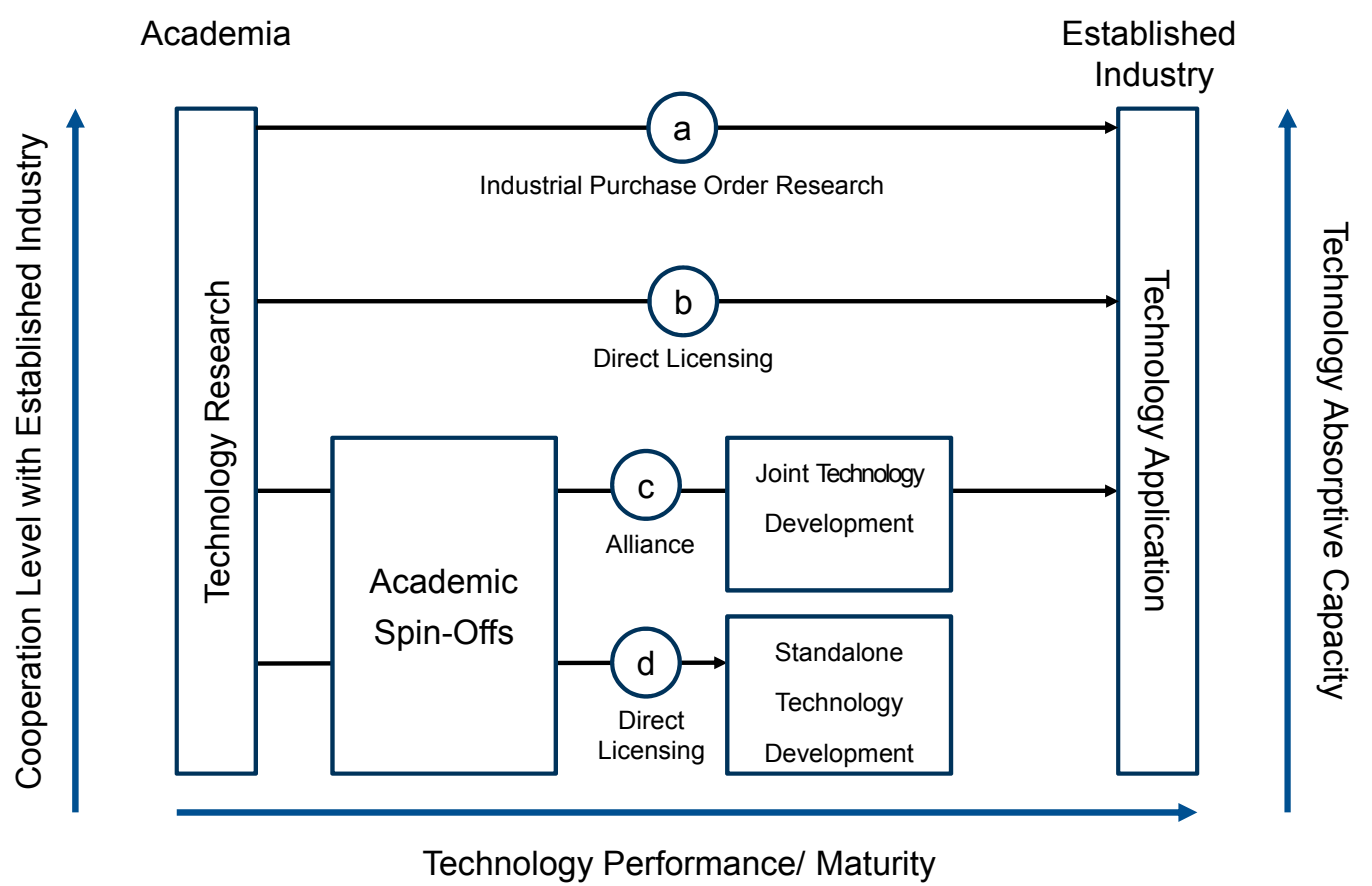

Figure 1. Technology transfer between academia and the established industry 
Table 1 summarizes the technology transfer vehicles and the capabilities which are necessary for academia and the established industry.

For technology transfer cases "a", academia relies on the capability and direct professional interaction of research institutes with industrial research partners. For "b", academia may act as an agent for technology licenses, identifying potential partners with the capacity to adopt the technology directly. In cases "c" and "d", industry technology absorption is low and academic incubation support is required. Given the advantageous performance of technology spin-offs which manage to negotiate an industrial alliance, a UTI will have to concentrate on the development of competencies, focusing on cases "c" and "d".

Acknowledging the obvious common characteristics of universities, three strategic advantages can be identified: (1) overview of ongoing research activities approaching a state of applied technology research; (2) unique early and credible access to research teams; and (3) a wide cross-industrial research network with the established industry. These advantages suggest positioning a UTI as a "Broker of Technology" using the internal university network opportunities, developing inventions, supporting the formation of technology spin-offs and preparing the industrial research network for alliances with these spin-offs.

Table 1. Technology transfer vehicle and capability between academia and the established industry

\begin{tabular}{|c|c|c|c|}
\hline Technology Transfer & Transfer Vehicle & Academic Capability & $\begin{array}{l}\text { Established } \\
\text { Industry Capability }\end{array}$ \\
\hline $\begin{array}{l}\text { Industrial } \\
\text { Purchase } \\
\text { Order } \\
\text { Research }\end{array}$ & $\begin{array}{l}\text { - Standardized R\&D } \\
\text { purchase order with } \\
\text { pre-defined IP and } \\
\text { licencing boundaries } \\
\text { at handover interface }\end{array}$ & $\begin{array}{l}\text { - Technology maturity and } \\
\text { incubation between } \\
\text { research partners } \\
\text { - Transfer relation managed } \\
\text { directly by research partner }\end{array}$ & $\begin{array}{l}\text { - High technology absorptive } \\
\text { capacity with strong specific } \\
\text { R\&D Interface } \\
\text { - Technology screening and } \\
\text { incubation capability }\end{array}$ \\
\hline $\begin{array}{l}\text { Direct Licensing } \\
\text { With } \\
\text { Established } \\
\text { Industry }\end{array}$ & $\begin{array}{l}\text { - Technology license to } \\
\text { industry without strong } \\
\text { research cooperation }\end{array}$ & $\begin{array}{l}\text { - High technology maturity } \\
\text { - Transfer relation managed } \\
\text { by technology transfer } \\
\text { office } \\
\text { - Technology marketing }\end{array}$ & $\begin{array}{l}\text { - Technology absorptive } \\
\text { capacity needed with } \\
\text { limited R\&D Interface } \\
\text { - Limited technology } \\
\text { incubation }\end{array}$ \\
\hline $\begin{array}{l}\text { Alliance } \\
\text { Spin-Off }\end{array}$ & $\begin{array}{l}\text { - Technology license to } \\
\text { academic spin-off with } \\
\text { joint research } \\
\text { cooperation }\end{array}$ & $\begin{array}{l}\text { - bint technology incubation } \\
\text { - Transfer relation managed } \\
\text { by academic spin-off }\end{array}$ & $\begin{array}{l}\text { - Limited technology } \\
\text { absorptive capacity } \\
\text { - Strong non technology } \\
\text { specific R\&D interface }\end{array}$ \\
\hline $\begin{array}{l}\text { Direct } \\
\text { Licensing } \\
\text { To Academic } \\
\text { Standalone } \\
\text { Spin-Offs }\end{array}$ & $\begin{array}{l}\text { - Technology license to } \\
\text { academic standalone } \\
\text { spin-off }\end{array}$ & $\begin{array}{l}\text { - Technology screening and } \\
\text { incubation capability } \\
\text { - Technology transfer office } \\
\text { and research institute } \\
\text { develop license and } \\
\text { foundation agreement } \\
\text { with spin-off }\end{array}$ & $\begin{array}{l}\text { - Limited interaction with } \\
\text { established industry }\end{array}$ \\
\hline
\end{tabular}

Three main phases can be derived for a UTI to support technology transfer and build the necessary expertise:

Pre-Incubation Phase: With a university's unique ability to screen, and early access to technology research teams, a UTI should be able to support the identification and invention phase of the technology transfer.

Formation Phase: A university can also support the build-up of a technology spin-off which is prepared to become the transfer vehicle towards technology demonstration.

Alliance Development Phase: After foundation, the UTI should be well placed to support spin-offs and open up its industry partner network for them - acting as a broker for technology alliances.

Experience A: Development Phases

- Receptor's technology absorptive capacity drives technology transfer model

- A UTI builds competencies based on unique university characteristics

- overview of ongoing research activities

- unique early and credible access to research teams

- wide cross-industrial industry research network 


\section{Set Up of the UTI at ETHZ}

The UTI at the ETHZ is strategically placed between academia and industry. It is a non-profit organization funded by the university and its donors. According to the phases described, the UTI concentrates on building the following competences:

- Establishment of a program for technology inventors, to support screening in the pre-incubation phase. This helps a technology inventor to investigate the entrepreneurial potential of the technology for one and a half years.

- Education of technology talents and inventors towards entrepreneurship.

- Spin-off formation support in cooperation with the technology transfer office.

- Spin-off coaching following the "Broker of Technology" model, with the aims of identification and the development of industry alliances.

Table 2. Investigated technology spin-offs starting from different technology development levels

\begin{tabular}{|c|c|c|c|c|c|}
\hline Company & Apha & Beta & Gamma & Delta & Epsilon \\
\hline Industry & - Machines & $\begin{array}{l}\text { - Energy } \\
\text { Systems }\end{array}$ & $\begin{array}{l}\text { - Materials \& } \\
\text { Process } \\
\text { Technology }\end{array}$ & $\begin{array}{l}\text { - Process } \\
\text { Engineering }\end{array}$ & - Robotics \\
\hline Entry Stage & - Demonstrator & - Lab Prototype & - Demonstrator & - Lab Prototype & - Inventors Idea \\
\hline Qurrent Stage & - Alliance Demo & - Demonstrator & - Alliance Demo & - Demonstrator & - Alliance Product \\
\hline Technology & $\begin{array}{l}\text { - Bectric } \\
\text { Polymer } \\
\text { Actuation } \\
\text { Systems }\end{array}$ & $\begin{array}{l}\text { Thermoelectric } \\
\text { Generators with } \\
\text { Application in } \\
\text { Batteries, Solar }\end{array}$ & $\begin{array}{l}\text { - Ceramic } \\
\text { Process } \\
\text { Technology \& } \\
\text { Engineering }\end{array}$ & $\begin{array}{l}\text { - Gas } \\
\text { Capturing } \\
\text { Systems }\end{array}$ & $\begin{array}{l}\text { - Industrial } \\
\text { Inspection } \\
\text { Robotoics }\end{array}$ \\
\hline $\begin{array}{l}\text { Aliance } \\
\text { Dialogue }\end{array}$ & $\begin{array}{l}\text { - Large 日ectro } \\
\text { Corp. } \\
\text { - Large Machine } \\
\text { Corp. }\end{array}$ & $\begin{array}{l}\text { Large Chemical } \\
\text { Corporation }\end{array}$ & $\begin{array}{l}\text { - Large } \\
\text { Power } \\
\text { Corporation }\end{array}$ & - Process SME & $\begin{array}{l}\text { - Large Power } \\
\text { Corporation }\end{array}$ \\
\hline Foundation & $\cdot 2010$ & $\cdot 2009$ & • 2007 & • 2009 & • 2006 \\
\hline Ownership & - Mgmt. $100 \%$ & $\begin{array}{l}\text { - Mgmt. } 100 \% \\
\text { - Bus. Angle \& } \\
\text { Financier with } \\
\text { Convertible Bond }\end{array}$ & $\begin{array}{l}\text { - Mgmt. } 90 \% \\
\text { - Academia 10\% }\end{array}$ & $\begin{array}{l}\text { - Mgmt. } 66 \% \\
\text { - Bus. Angle } 34 \%\end{array}$ & $\begin{array}{l}\text { - Mgmt. 25\% } \\
\text { - Industry 51\% } \\
\text { - Academia 24\% }\end{array}$ \\
\hline Employees & $\cdot 2$ & - 11 & $\cdot 7$ & $\cdot 5$ & $\cdot 20$ \\
\hline Patents & $\cdot 2$ & $\cdot 2$ & $\cdot 1$ & $\cdot 2$ & $\cdot 6$ \\
\hline
\end{tabular}

Table 3. Investigated technology inventors starting from the UTI pre-incubation phase

\begin{tabular}{|c|c|c|c|c|c|}
\hline Company & Zeta & Eta & Theta & Iota & Kappa \\
\hline Industry & $\begin{array}{l}\text { - Transport } \\
\text { Systems }\end{array}$ & $\begin{array}{l}\text { - Nano Materials } \\
\text { \& Process } \\
\text { Technology }\end{array}$ & - Eectronics & $\begin{array}{l}\text { - Materials } \\
\text { \&Process } \\
\text { Technology }\end{array}$ & - Machines \\
\hline Entry Stage & - Inventor Idea & - Lab Demo & - Demonstration & $\begin{array}{l}\text { - Lab } \\
\text { Demonstration }\end{array}$ & - Inventor Idea \\
\hline Qurrent Stage & - Alliance Demo & - Demonstration & - Demonstration & $\begin{array}{l}\text { - Lab } \\
\text { Demonstration }\end{array}$ & - Aliance Demo \\
\hline Technology & $\begin{array}{l}\text { - Transport } \\
\text { Monitoring, } \\
\text { Simulation and } \\
\text { Planning Systems }\end{array}$ & $\begin{array}{l}\text { - Dental } \\
\text { Material }\end{array}$ & $\begin{array}{l}\text { - New Laser } \\
\text { System for } \\
\text { Spectroscopy }\end{array}$ & $\begin{array}{l}\text { - Fabric } \\
\text { Material }\end{array}$ & $\begin{array}{l}\text { - Adaptive } \\
\text { Systems } \\
\text { Design (Tools\& } \\
\text { Robotics }\end{array}$ \\
\hline $\begin{array}{l}\text { Aliance } \\
\text { Dialogue }\end{array}$ & $\begin{array}{l}\text { B2B E-Bike } \\
\text { SME }\end{array}$ & $\begin{array}{l}\text { - Gobal Dental } \\
\text { Company }\end{array}$ & - Laser SME & $\begin{array}{l}\text { - Material } \\
\text { Supplier }\end{array}$ & $\begin{array}{l}\text { - Actuator SME } \\
\text { - Medical SME }\end{array}$ \\
\hline Foundation & • 2011 & • 2011 & • 2011 & - Founding Stage & • 2011 \\
\hline Ownership & $\begin{array}{l}\text { - Mgmt. 85\% } \\
\text { - Industry } \\
\text { Partner 15\% }\end{array}$ & $\begin{array}{l}\text { - Mgmt. } 80 \% \\
\text { - Academia 20\% }\end{array}$ & $\begin{array}{l}\text { - Mgmt. } 80 \% \\
\text { - Academia } 20 \%\end{array}$ & & $\begin{array}{l}\text { - Mgmt. } 67 \% \\
\text { - Academia 33\% }\end{array}$ \\
\hline Employees & $\cdot 2$ & $\cdot 2$ & $\cdot 3$ & - Inventor & $\cdot 2$ \\
\hline Patents & - - & $\cdot 1$ & $\cdot-$ & $\cdot 2$ & $\cdot 2$ \\
\hline
\end{tabular}


Table 2 illustrates the five spin-offs and Table 3 the five technology inventors who were selected and participating in this study. The selection was driven by the development stages of the inventors and spin-offs, and by the necessity to identify representatives for each stage. The selected technology inventions and spin-offs covered all phases, from the inventor's first idea to product introduction in an industry alliance.

\subsection{Pre-Incubation Phase}

Technological inventions and possible entrepreneurial conversion are frequent topics for discussion between researchers and their academic supervisors. The time window for such discussions is primarily short and it is important that the UTI is prepared to help pursue the invention and support the inventors in the evaluation process. The inventors in this case study had the opportunity to present their inventions to a UTI board which was represented by university technology transfer and industrial relation managers, academic experts and experienced technology spin-off coaches. Selection criteria of the board members were technical feasibility and the soundness of the invention, maturity of the technological application, and impact and importance of the invention. Selected inventors were then financially supported with an inventor's grant and were coached by the UTI.

The UTI "Broker of Technology" coaching program focused on the development of a business case for the conversion of the invention into a technology spin-off, suitable for an alliance negotiation with an industry partner. The program followed a four-step approach, clarifying critical issues and developing the inventor's idea into a business plan and spin-off formation.

Uniqueness: Clarification of the ownership of intellectual property (IP, including patents, trademarks, copyrights or design and trade secrets) is the first step to confirm the uniqueness and accessibility of the technology invention. To ensure the potential take-over of the IP, inventors must have prior knowledge of patents and they must be willing to license to a potential spin-off. This is not always easy to assess, as in long-term research programs with many participants who often come from industry, the origin of an invention can be disputed. Sometimes inventors rely only on an agreement guaranteeing freedom to operate, however uniqueness is weakened by limited protection. With an early-stage technology invention, it is also useful to explore the number of research teams working in a similar area of research and to investigate whether other spin-offs have already been set up.

Feasibility: Feasibility assessment starts with the identification of potential bottlenecks. The inventors need to prepare a "green field" infrastructure investment calculation which aims for the complete midterm infrastructure independence of a potential spin-off. An assessment of dependency on a single supplier, and therefore supply chain dependence, is also relevant and led to various redundancy problems in the case studies. To prepare the market, understanding a first critical discussion of the usefulness of the invention for different users is central at this stage.

Technology Maturity: Depending on the type of technology invention, inventors should explore different applications and scenarios for resources and business set-up. The result is preferably a complete resources and cost breakdown for a potential multi-year spin-off development, which allows inventors to start estimating their investment in the technology introduction. It is important that the inventors describe and present a feasible, conservative demonstration and industrialization scenario which can later form the basis of the technology lifecycle discussions with the established industry.

Entrepreneurial Setting: In the early technology invention phase, it is beneficial for the inventor to seek a role as a "Broker of Technology." Of course, this is not necessarily consistent with the role of an entrepreneur. However, in the early stages, it is not at all clear whether an invention warrants entrepreneurial activity, so the alliance approach helps to clarify a spin-off's feasibility and risk exposure.

Experience B: Pre-Incubation

- To access an early invention stage and to shape the inventors network, the UTI needs to build instruments to finance and support the investigation of technology invention.

\subsection{Formation Phase}

The main question during a spin-off's formation phase is the capability of the different technology types and an early business model build-up. The technology perspective of this study allowed for the definition of technology invention types. The formation of these types developed by the spin-offs and inventors investigated could be reduced to a pattern, which first made it possible to ascertain their capability, building absorptive capacity and then made it possible to set up a business model. The following four technology invention type patterns were identified; they focused on the building of a spin-off model and should not be confused with invention definitions in intellectual property. 
Material Inventions: Material invention types form the basis of many technology inventions where the technology transfer focuses on the material demonstration, testing and production scaling from a laboratory via a number of demonstrators to industrial production in size and quality (e.g., material for a new laser).

Process Inventions: A process invention may replace an existing process, achieving advantageous new results (e.g., the method of building a new laser).

Subsystem Inventions: Subsystem or component technologies are not a product as such but are part of a system technology and lead to an improved system. After demonstration, the development focus is on integration with existing systems and understanding the system-specific process and operation criteria (e.g., developing a new laser for spectroscopic systems).

System Inventions: System technologies aim to replace existing systems or are entirely new. The development focus after demonstration is on industrialization, production, supply chain, marketing and sales (e.g., developing a new laser principle).

All the spin-offs in this study, and probably the majority of technology spin-offs in general, will resemble the model described in Table 4, which shows a framework to position spin-offs according to the type of their technology invention. Spin-offs may also be prepared to develop parallel invention types.

The build-up of a spin-off's capabilities starts with R\&D and industrialization development. This applies to all technology inventions and is based on their R\&D acumen. The spin-offs build their capability towards technology demonstration, and industrialize their production, process and integration capabilities. For the systems and subsystems field test, the main focus is on production and supply chain capability, whereas for process and material inventions, the demonstration scaling towards a stable production process is paramount. Spin-offs generate revenues with different business models according to their varying capability settings, and can all generate R\&D service revenues. Engineering efforts in production, process and integration can be sold externally for material, process and subsystem inventions, whereas system inventions without alliance partners usually have to manage with an industrialization phase lacking external revenue. The business model for material and process technology invention types generally includes a license for limited technology or market application.

The role of the UTI is to support the spin-offs with positioning and alliance identification. Identifying the technology invention type, and applying subsequent capability and business model ramp-ups in the early formation phase, allows for the cost structure to be fixed and more efficient business planning. Coaching the spin-offs towards a transparent business approach, the UTI will increase their credibility and readiness for industry alliances.

Table 4. Technology invention type and spin-off positioning

\begin{tabular}{|c|c|c|c|c|}
\hline Technology Type & $\begin{array}{l}\text { Capability } \\
\text { Build Up }\end{array}$ & $\begin{array}{l}\text { Business Model } \\
\text { Build Up }\end{array}$ & Alliance Partner & $\begin{array}{l}\text { Spin-Offs \& } \\
\text { Inventors }\end{array}$ \\
\hline $\begin{array}{l}\text { Material } \\
\text { Invention }\end{array}$ & $\begin{array}{l}\text { Material R\&D } \\
\text { - Material Production } \\
\text { Engineering } \\
\text { - Material Process Integration } \\
\text { - Supply Chain } \\
\text { - Technical Sales }\end{array}$ & $\begin{array}{l}\text { - R\&D Service } \\
\text { - Production Engineering } \\
\text { - Integration Engineering } \\
\text { - Licensing } \\
\text { - Small Batch Material Sales }\end{array}$ & $\begin{array}{l}\text { - Niche Material Supplier } \\
\text { - Low Technology } \\
\text { Absorption Partner }\end{array}$ & $\begin{array}{l}\text { - Iota } \\
\text { - Gamma } \\
\text { - Eta }\end{array}$ \\
\hline $\begin{array}{l}\text { Process } \\
\text { Invention }\end{array}$ & $\begin{array}{l}\text { - Process R\&D } \\
\text { - Process Engineering } \\
\text { - Process Integration }\end{array}$ & $\begin{array}{l}\text { - R\&D Service } \\
\text { - Process Engineering } \\
\text { - Integration Engineering } \\
\text { - Licensing }\end{array}$ & $\begin{array}{l}\text { - Process Industry with } \\
\text { low Technology } \\
\text { Absorption } \\
\text { - Niche Process } \\
\text { Application Partner }\end{array}$ & $\begin{array}{l}\text { - Delta } \\
\text { - Alpha } \\
\text { - Beta I }\end{array}$ \\
\hline $\begin{array}{l}\text { Subsystem } \\
\text { Invention }\end{array}$ & $\begin{array}{l}\text { - Subsystem R\&D } \\
\text { - Subsystem Integration } \\
\text { - Subsystem Production } \\
\text { - Supply Chain } \\
\text { - Technical Sales }\end{array}$ & $\begin{array}{l}\text { - R\&D Service } \\
\text { - Integration Engineering } \\
\text { - Product Sales } \\
\text { - Product Service Spares \& } \\
\quad \text { Maintenance }\end{array}$ & $\begin{array}{l}\text { - System Provider } \\
\text { - Niche Subsystem } \\
\text { Provider with low } \\
\text { Technology Absorption } \\
\text { - Technical Marketer }\end{array}$ & $\begin{array}{l}\text { - Beta II } \\
\text { - Kappa II. } \\
\text { - Zeta }\end{array}$ \\
\hline $\begin{array}{l}\text { System } \\
\text { Invention }\end{array}$ & $\begin{array}{l}\text { - System R\&D } \\
\text { - System Industrialization } \\
\text { - System Production } \\
\text { - Supply Chain } \\
\text { - System Sales } \\
\text { - System Service }\end{array}$ & $\begin{array}{l}\text { - R\&D Service } \\
\text { - Product Sales } \\
\text { - Product Service Spares \& } \\
\text { Maintenance }\end{array}$ & $\begin{array}{l}\text { - Niche System Provider } \\
\text { - System Provider with } \\
\text { low Technology } \\
\text { Absorption e.g.aged } \\
\text { out } \\
\text { - Marketer } \\
\text { - Supply Chain Partner }\end{array}$ & $\begin{array}{l}\text { - Epsilon } \\
\text { - Theta } \\
\text { - Kappa I }\end{array}$ \\
\hline
\end{tabular}


Experience C: Spin-Off Formation

- Technology invention types implicate a first specific capability and business build-up in the spin-off formation.

- UTI "Broker of Technology" model prepares credibility and trustworthiness of the spin-off's capability and business model build-up for a technology alliance dialogue with industry.

\subsection{Alliance Development Phase}

The selection of potential industry partners depends upon their technology absorptive capacity and their industrialization and market capability. A matrix has been defined to visualize and discuss the industrial partner identification procedure - not to divide the world neatly into four quadrants - as boundaries may overlap and positions can move. Figure 2a illustrates a framework to determine potential spin-off alliance partners. Figure $2 \mathrm{~b}$ shows the assessment of potential alliance partners by the inventions and spin-offs in this study.

The spin-offs and inventors have evaluated and assessed the technology absorptive capacity of their alliance partners, as well as their potential industry partners' overall R\&D capability and specific technology and engineering know-how. The industrialization and market capability axis has been evaluated according to market access and maturity, customer access, industrialization readiness and R\&D target definition capability. Spin-offs have very strong technology know-how and need to build industrialization and market capabilities. Appropriate industry partners are therefore those which are ready to support industrialization and the market approach. However, partners with a high technology absorptive capacity can license technology directly from universities, and from the spin-offs' point of view, may appear to be competitors. Industry players with little technology absorptive capacity, but with experience in the market and industrialization expertise, could build an alliance with the aim of reaching the market with new breakthrough products, thus developing the spin-off into a technology and product supplier.

a)

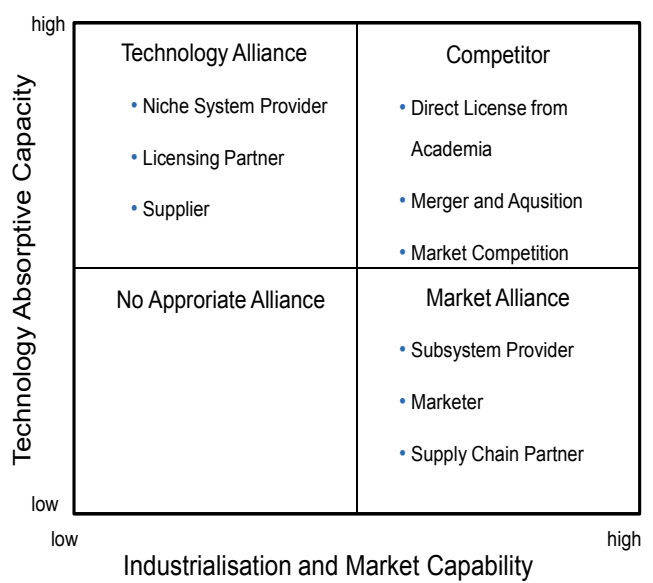

b)

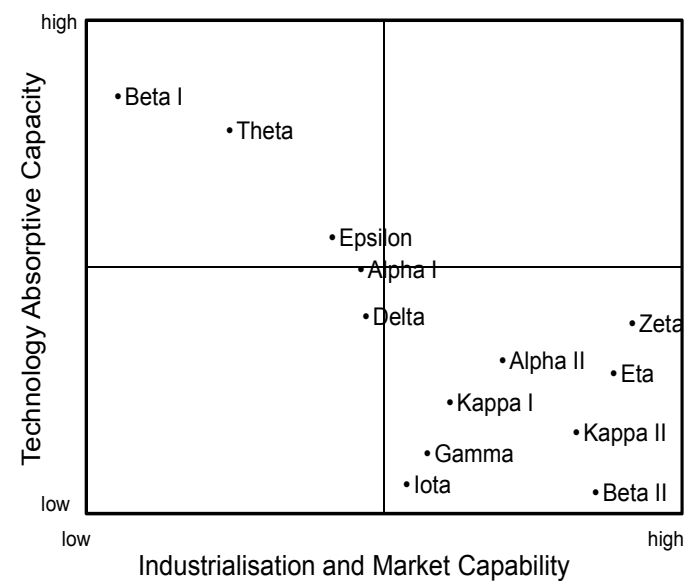

Figure 2a. Framework for technology spin-off industrial alliance partner

Figure 2b. Assessment of potential industry alliance partners by technology spin-offs

On the other hand, players with strong technology absorption, but limited market and industrialization expertise, can develop the spin-off into a technology provider and license the technology for a limited niche market application. The UTI encourages the spin-off to screen for market and technology players to cluster the market and accordingly approach the established industry.

The spin-offs owned attractive and outstanding technologies and many of them successfully negotiated R\&D contracts with the industry. However, R\&D efforts slowed down depending on how the industry partner rated the maturity of the technology, and whether or not it could quickly be demonstrated. It is therefore critical that the industry dynamics are understood. The danger of poor expectation management is that spin-off R\&D has to constantly investigate industry applications which are then postponed. 


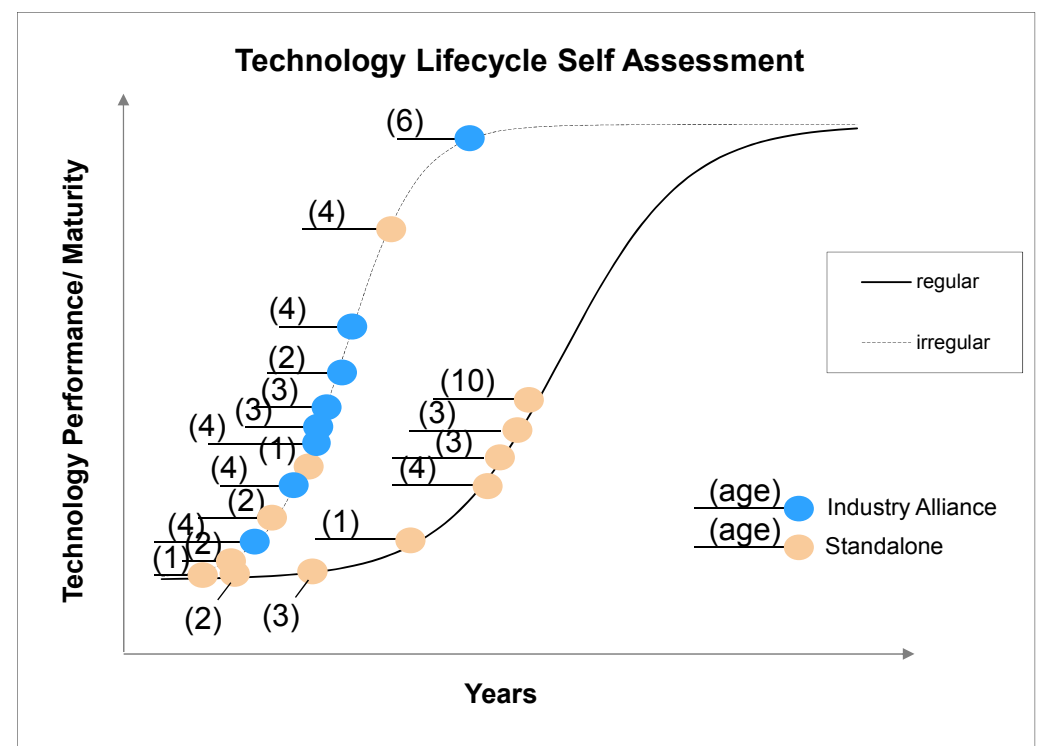

Figure 3. Technology lifecycle positioning of 12 standalone and 8 industry alliance spin-offs from ETHZ; single interview self-assessment; adopted from Hess, Suhrbeer and Siegwart (2012)

Hess, Suhrbeer and Siegwart (2012) found, in study of 20 ETHZ spin-offs shown in Figure 3, that an important factor influencing the alliance development phase is the spin-off's perception of the technology and its lifecycle behavior, and, in particular, the perception of potential industry partners. For alliance discussions, it is important to identify industries which will perceive the technology lifecycle as "irregular" and might be willing to risk investing in a joint development alliance. On the other hand, it is difficult to negotiate with a partner who perceives the presented technology as following a "regular" technology lifecycle. The UTI method encourages spin-offs to rate their technologies early and actively seek positioning on lifecycle curves with "irregular" dynamics. An established industrial player usually follows a strategic rationale and bases his/her decisions on a defined technological environment of strategic importance. Technologies appearing on this radar which fall into the category of strategic importance will most likely trigger immediate action; however, the quality of the action depends heavily on the estimation of the technical and market barriers which are anticipated. For low barriers, the industry player will be inclined to adopt technology internally. Higher barriers will normally increase risk averseness and collaboration will be more likely. The risk level will be reduced with positive answers regarding the technology's maturity, experience and complexity, existing competing technologies, availability and skill set of resources, and other entrepreneurial activity in the technological area. A spin-off communicating as a "Broker of Technology" for collaboration should address these points proactively and present a conservative picture of "how it could be done".

If a UTI coaching model can successfully help spin-offs recognize their role in the technology transfer process, they will fill a gap in cooperation between academia and industry, and encourage the development of alliances. Building acceptance, and illustrating a risk-mitigated way to bring a technology to market in an alliance, will overcome mutual concerns and pave the way to successful cooperation.

Experience D: Alliances Development

- Alliance partner can be identified according to technology absorptive capacity, industrialization and market capability.

- UTI should encourage early technology lifecycle positioning and prioritize selection criteria for partners who might perceive a spin-off as being on an "irregular" dynamics cycle.

\section{Proposition of a "Broker of Technology" Model for UTI's}

The authors would like to formulate three propositions as to how a university should position a UTI as a "Broker of Technology".

Proposition I:

- Based on university's unique research overview and access to research teams, a UTI builds technology pre-incubation skills, like an inventors grant, and develops capabilities to investigate uniqueness, feasibility, technology maturity and an entrepreneurial setting. 
Academia is the earliest point of access to technology (Etzkowitz, 2002) and a UTI model, as presented, will need to reflect on Experience A: "Development Phases". It should support the incubation of technologies from research teams in various ways, including screening and identifying technology, as well as assessing and developing them (Autio, 1997). A UTI helps to estimate the time technologies needed to reach the demonstration stage, while also ensuring the efficient flow of knowledge and technology transfer (Squicciarini, 2008; Peters et al., 2004). In Experience B: "Pre-Incubation", a finance instrument for inventor's technology development and preparation for a credible alliance positioning of the spin-off (Schwartz, 2009) is central.

Proposition II:

- By applying technology invention types and the implicated capability and business model set-ups, a UTI will increase spin-off credibility and the pace of spin-off creation in the formation phase.

Previous studies have observed a spin-off in a technology and knowledge mediator role (Fontes, 2005; Etzkowitz, 2002), supported by Experience C "Spin-off Formation". Increasing credibility and trust (Pérez and Martinez, 2003) with the respective capability and business model for a spin-off formation (Schwartz, 2009) based on technology invention types is essential. In addition, our study confirms that spin-offs need to build network capability quickly after foundation (Walter et al., 2006) and their technology absorptive capacity should be visible in their spin-off setting to build alliances.

Proposition III:

- A university's reputation and contact within a wide cross-industry research network allows a UTI to support accessibility in the alliance phase for inventors and spin-offs by a technology lifecycle positioning and alliance partner evaluation, according to their technology absorptive capacity and their industrialization and market capability.

Experience D "Alliance Development" allows for evaluating industrial alliance partners from a spin-off point of view. Early alliances and networks are a success factor for spin-off growth (Lindelöf and Löfsten, 2003; Pérez and Martinez, 2003). A UTI should enable spin-offs to access the industrial network of the university and help partner identification according to their technology absorptive capacity and industrialization and market capability (Walter et al., 2006; Hindle and Yencken, 2004).

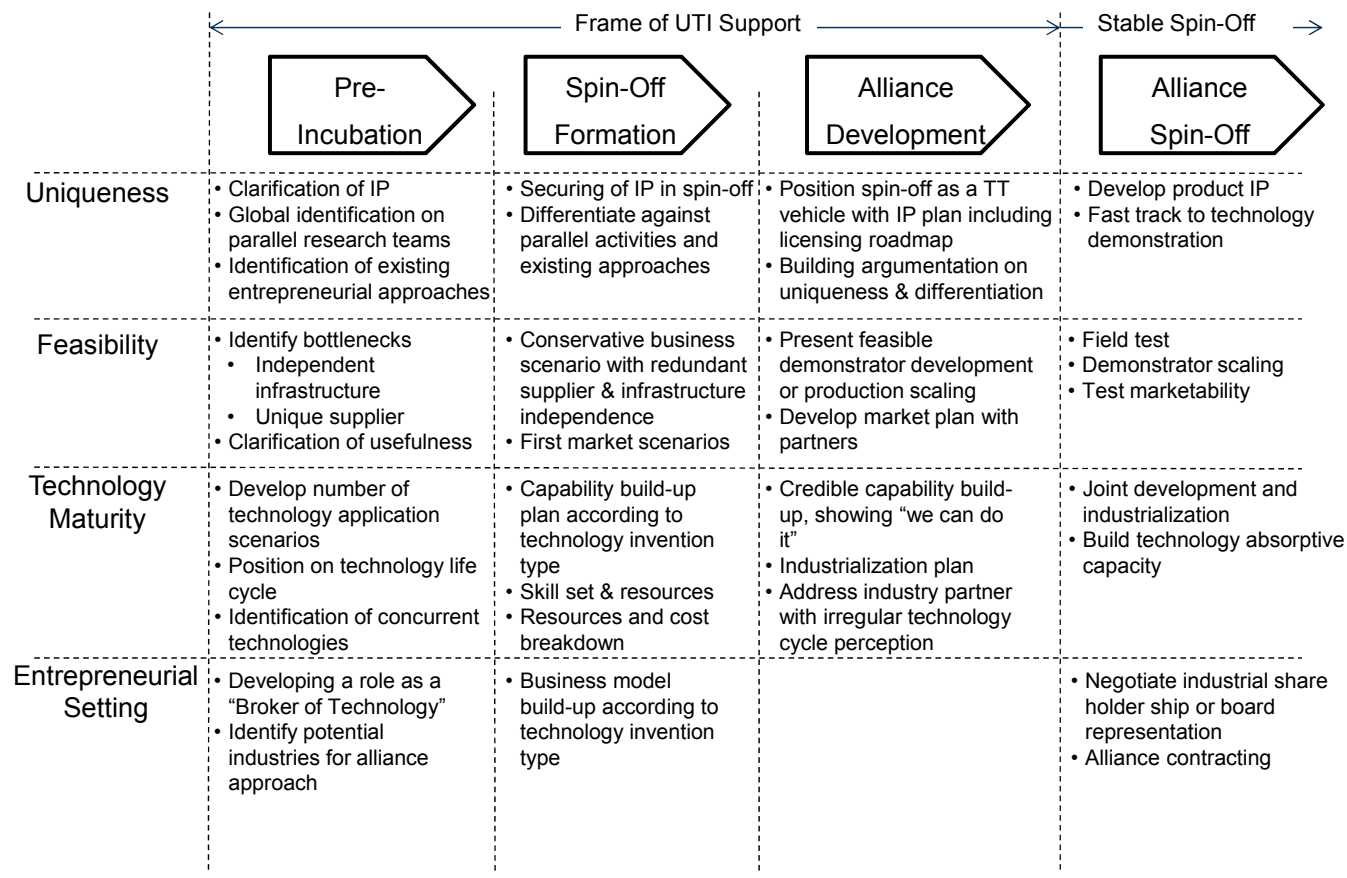

Figure 4. University technology incubator model as a "Broker of Technology"

As we have explained the "Broker of Technology" model for a UTI as summarized in Figure 4, the strategic intention of the UTI is to stabilize inventions from the pre-incubation, formation and alliance development phases 
preferably towards a spin-off in an industrial alliance. Following given structure streams of uniqueness, feasibility, technology maturity and entrepreneurial setting, the UTI can review, induce and develop spin-offs. Particularly in the pre-incubation and formation phases of an invention, the UTI should develop the expertise to clarify bottlenecks and feasibility. Arguing that technology maturity and enterprise setting can only be reviewed by entrepreneurial or venture experts (Walter et al., 2006), the authors would dispute that in these early stages technology skills are dominant. The identification of the technology invention type, and the selection of the capability and business build-up as presented above, is sufficient for a first entrepreneurial positioning. It is the main target of the UTI, as a "Broker of Technology", to thoroughly clarify, position and prepare the technology demonstration so it can credibly be presented (Schwartz, 2009) to industry, identifying interest and initiating the transmission process with mutual learning and joint technology development.

\section{Results and Conclusion}

Learning from the above, this publication aimed to better understand and discuss how a university should position a UTI to improve technology transfer in R\&D networks or alliances between spin-offs and an established industry. The authors have analyzed the pre-incubation, formation and alliance development phase of spin-offs and inventors, and discussed the role of the UTI.

The findings are:

- The industrial partner's technology absorptive capacity drives the overall technology transfer model

- The UTI can build upon the following university characteristics: (1) overview of ongoing research activities, (2) unique and early access to research teams, and (3) wide cross-industrial research networks

- A UTI needs to develop a funding instrument for the investigation of the pre-incubation technology invention phase

- To accelerate the formation process, the UTI can propose technology invention types, which implicate a capability and business build-up in the spin-off formation phase

- The UTI can support the alliance development phase by identifying an alliance partner according to their technology absorptive capacity and industrialization and market capabilities

- The UTI can encourage alliances when spin-offs can position themselves on a technology lifecycle which the alliance partner perceives as irregular dynamic behavior

\section{Discussion and Implications for Practice and Research}

The authors have shown that technology alliances between academic spin-offs and the established industry are a natural way to develop technologies efficiently, which is confirmed by the literature (Fontes, 2005; Hess and Siegwart, 2012; Lindelöf and Löfsten, 2003). In a UTI model, starting to identify potential receptors with respective technology absorptive capacity in the early formation phases is an efficient and practical approach (Pérez and Martinez, 2003; Cohen and Levinthal, 1989; Zahra and George, 2002). Placing inventors' technological expertise in a spin-off, and forming an alliance with industrial expertise, increases speed to innovation (Barringer and Bluedorn, 1999). As the technologies are early stage and often breakthrough, the UTI's role of a "Broker of Technology" can help spin-offs to credibly position themselves to gain legitimacy and demonstrate reliability and trustworthiness (Schwartz, 2009; Rothaermel and Thursby, 2005b). Lacking business and market skills (Chiesa and Piccaluga, 2000), but positioned according to the various technology invention types, a spin-off with strong technology and R\&D skills will demonstrate readiness for cooperation. They will also compensate for deficiencies and quickly stabilize in an industrial alliance (Stankiewicz, 1994).

The literature emphasizes the need for a clear technology strategy for UTIs and a differentiation from technology parks or other innovation incubators (Becker and Gassmann, 2006; Bergek and Norrman, 2008). A UTI based on unique university characteristics, strategically positioned as a "Broker of Technology" model, finds such a position. The cases presented illustrate that a UTI following the proposed processes can successfully screen and develop early-stage technological innovation (Etzkowitz, 2002).

Hackett and Dilts (2004), in their systematic incubator literature review, emphasized focus on the incubation process to explain phenomena like new venture formation, venture development, new product development and business assistance, rather than on the incubator facility. The authors also identified a UTI process instrument to accelerate the development of an invention towards a spin-off in network alliances (Walter et al., 2006). 


\section{References}

Ahuja, G., Lampert, C. M. (2001). Entrepreneurship in the large corporation: a longitudinal study of how established firms create breakthrough inventions. Strategic Management Journal, 22: 521-543. http://dx.doi.org/10.1002/smj.176

Autio, E. (1997). New, technology-based firms in innovation networks symplectic and generative impacts. Research Policy, 26, 263-281. http://dx.doi.org/10.1016/S0048-7333(96)00906-7

Barringer, B. R., Bluedorn, A. C. (1999). The relationship between corporate entrepreneurship and strategic $\begin{array}{llll}\text { management. Strategic } & \text { Management } & \text { Journal, } & \text { 421-444. }\end{array}$ http://dx.doi.org/10.1002/(SICI)1097-0266(199905)20:5<421::AID-SMJ30>3.0.CO;2-O

Becker, B., Gassmann, O. (2006). Corporate Incubators: Industrial R\&D and What Universities Can Learn from Them. Journal of Technology Transfer, 31, 469-483. http://dx.doi.org/10.1007/s10961-006-0008-6

Bergek, A., Norrman, C. (2008). Incubator best practice: A framework. Technovation, 28, 20-28, http://dx.doi.org/10.1016/j.technovation.2007.07.008

Burlem, W. S. (1977). Motivations for Technology Transfer. Journal of Technology Transfer, 1(2). http://dx.doi.org/10.1007/BF02622189

Chandy, R. K., Tellis, G. J. (2000). The Incumbent's Curse? Incumbency, Size, and Radical Product Innovation. Journal of Marketing, Vol. 64 (July), 1-17. http://dx.doi.org/10.1509/jmkg.64.3.1.18033

Chesbrough, H. (2003). Open Innovation. The New Imperative for Creating and Profiting from Technology. Boston Massachusetts: Harvard Business Review Press.

Chiesa, V., Piccaluga, A. (2000). Exploitation and diffusion of public research: the case of academic spin-off companies in Italy. $R \& D$ Management, 30, 4, 329-339. http://dx.doi.org/10.1111/1467-9310.00187

Christensen, C. M. (2003). The Innovator's Dilemma. New York: Harper Business Essentials Edition.

Clarysse, B., Moray, N. (2004). A process study of entrepreneurial team formation: the case of a research-based spin-off. Journal of Business Venturing, 19, 55-79. http://dx.doi.org/10.1016/S0883-9026(02)00113-1

Cohen, W. M., Levinthal, D. A. (1989). Innovation and Learning: The Two Faces of R\&D. The Economic Journal, Vol. 99, No. 397 (September), pp. 569-596. http://dx.doi.org/10.2307/2233763

Colombo, M. G., Delmastro, M. (2002). How effective are technology incubators? Evidence from Italy. Research Policy, 31, 1103-1122. http://dx.doi.org/10.1016/S0048-7333(01)00178-0

Eisenhardt, K. M., Graebner, M. E. (2007). Theory Building From Cases: Opportunities and Challenges. Academy of Management Journal, Vol. 50, No.1, 25-32. http://dx.doi.org/10.5465/AMJ.2007.24160888

Etzkowitz, H. (2002). Business incubators. Incubation of incubators: innovation as a triple helix of university-industry-government networks. Science and Public Policy, Vol. 29, No. 2 (April), 115-128. http://dx.doi.org/10.3152/147154302781781056

Fontes, M. (2005). The process of transformation of scientific and technological knowledge into economic value $\begin{array}{lllll}\text { conducted by biotechnology } & \text { spin-offs. } & \text { Technovation, } & 25, & 339-347 .\end{array}$ http://dx.doi.org/10.1016/j.technovation.2003.08.004

George, G., Zahra, S. A., Wood, D. R. (2002). The effects of business-university alliances on innovative output and financial performance: a study of publicly traded biotechnology companies. Journal of Business Venturing, 17, 577-609. http://dx.doi.org/10.1016/S0883-9026(01)00069-6

Gilbert, C. G. (2005). Unbundling the structure of inertia: resource versus routine rigidity. Academy of Management Journal, Vol. 48, No. 5 (October), 741-763. http://dx.doi.org/10.5465/AMJ.2005.18803920

Hackett, S. M., Dilts, D. M. (2004). A Systematic Review of Business Incubation Research. Journal of Technology Transfer, 29, 55-82. http://dx.doi.org/10.1023/B:JOTT.0000011181.11952.0f

Hess, S., Siegwart, R. Y. (2012). R\&D Venture: proposition of a technology transfer concept for breakthrough technologies with R\&D cooperation: A case study in the energy sector. Journal of Technology Transfer. http://dx.doi.org/10.1007/s10961-012-9249-8 
Hess, S., Suhrbeer, S., Siegwart, R. Y. (2012). The Impact of Collaborative Innovation between established Industry and Academic Technology Spin-Offs. Continuous Innovation Network, $13^{\text {th }}$ international CINet Conference, Rome, Italy.

Hess, S., Zwicker, E. (2009). Schnellere Technologie-Entwicklung dank agilen Start-up-Unternehmen. io new management, Nr. 3, 60-63.

Hindle, K., Yencken, J. (2004). Public research commercialisation, entrepreneurship and new technology based firms: an integrated model. Technovation, 24, 793-803. http://dx.doi.org/10.1016/S0166-4972(03)00023-3

Lindelöf, P., Löfsten, H. (2003). Science Park Location and New Technology-Based Firms in Sweden - Implications for Strategy and Performance. Small Business Economics, 20: 245-258. http://dx.doi.org/10.1023/A:1022861823493

Masterplan Cleantech Schweiz (2010). Bern: Eidgenössisches Volkswirtschaftsdepartement EVD.

Mian, S. A. (1997). Assessing and managing the university technology business incubator: An integrative framework. Journal of Business Venturing, 12, 251-285. http://dx.doi.org/10.1016/S0883-9026(96)00063-8

Mowery, D. C., Nelson, R. R., Martin, B. R. (2010). Technology policy and global warming: Why new policy models are needed (or why putting new wine in old bottles won't work). Research Policy, 39, 1011-1023. http://dx.doi.org/10.1016/j.respol.2010.05.008

Muscio, A. (2010). What drives the university use of technology transfer offices? Evidence from Italy. Journal of Technology Transfer, 35: 181-202. http://dx.doi.org/10.1007/s10961-009-9121-7

Pérez, M., Martinez A. (2003). The development of university spin-offs: early dynamics of technology transfer and networking. Technovation, 23, 823-831. http://dx.doi.org/10.1016/S0166-4972(02)00034-2

Peters, L., Rice, M., Sundararajan, M. (2004). The Role of Incubators in the Entrepreneurial Process. Journal of Technology Transfer, 29, 83-91. http://dx.doi.org/10.1023/B:JOTT.0000011182.82350.df

Rohrbeck, R., Heuer, J., Arnold, H. (2006). The Technology Radar - an Instrument of Technology Intelligence and Innovation Strategy. The 3rd IEEE Conference on Management of Innovation and Technology. Singapore: IEEE Conference.

Rothaermel, F. T., Thursby, M. (2005a). Incubator firm failure or graduation? The role of university linkages. Research Policy, 34, 1076-1090. http://dx.doi.org/10.1016/j.respol.2005.05.012

Rothaermel, F. T., Thursby, M. (2005b). University incubator firm knowledge flows: assessing their impact on incubator firm performance. Research Policy, 34, 305-320, http://dx.doi.org/10.1016/j.respol.2004.11.006

Schwartz, M. (2009). Beyond incubation: an analysis of firm survival and exit dynamics in the post-graduation periode. Journal of Technology Transfer, 34: 403-421. http://dx.doi.org/10.1007/s10961-008-9095-x

Squicciarini, M. (2008). Science Parks' tenants versus out-of-Park firms: who innovates more? A duration model. Journal of Technology Transfer, 33: 45-71. http://dx.doi.org/10.1007/s10961-007-9037-z

Stankiewicz, R. (1994). Spin-off companies from universities. Science and Public Policy, 21(2), 99-107.

Swiss Federal Council (1991). Swiss Federal Law on the Swiss Federal Institutes of Technology (Bundesgesetz über die Eidgenössischen Technischen Hochschulen). ETH Law of 4 October 1991 (Status as of 1. August 2008). The Federal Assembly of the Swiss Confederation.

Toole, A. A., Turvey, C. (2009). How does initial public financing influence private incentives for follow-on investment in early-stage technologies? Journal of Technology Transfer, 34: 43-58. http://dx.doi.org/10.1007/s10961-007-9074-7

Tornatzky, L. G., Fleischer, M. (1990). The Processes of Technological Innovation. Massachusetts / Toronto: Lexington Books.

Tripsas, M. (2008). Customer Preference Discontinuities: A Trigger for Radical Technological Change. Managerial and Decision Economics, 29: 79-97. http://dx.doi.org/10.1002/mde.1389

Tushman, M. L., O’Reilly, III, C. A. (1996). Ambidextrous Organization: Managing Evolutionary and Revolutionary Change. California Management Review, 38, (4), 8-30. http://dx.doi.org/10.2307/41165852

Utterback, J. M., Abernathy, W. J. (1975). A Dynamic Model of Process and Product Innovation. OMEGA, The International Journal of Management and Science, Vol. 3, No. 6, 639-656. 
Walter, A., Auer, M., Ritter, T. (2006). The impact of network capabilities and entrepreneurial orientation on university spin-off performance. Journal of Business Venturing, 21, 541-567. http://dx.doi.org/10.1016/j.jbusvent.2005.02.005

Wiggins, J., Gibson, D. V. (2003). Overview of US incubators and the case of the Austin Technology Incubator. International Journal Entrepreneurship and Innovation Management, Vol. 3, Nos. 1/2, pp. 56-66. http://dx.doi.org/10.1504/IJEIM.2003.002218

Williams, F. R., Gibson, D. V. (1990). Technology Transfer: A communication perspective. Newbury Park, California: Sage Publications.

Yin, R. K. (2009). Case Study Research. Design and Methods. Fourth Edition. Thousand Oaks, California: Sage Publications.

Zahra, S. A., George, G. (2002). Absorptive Capacity: A Review, Reconceptualization, and Extension. The Academy of Management Review, Vol. 27, No. 2 (April), pp. 185-203. 